\title{
The Correlation between Serum Vascular Endothelial Growth Factor and Lipid Profile in Type 2 Diabetes Mellitus
}

\author{
Rusdiana Rusdiana $^{1 *}$, Sry Suryani Widjaja ${ }^{1}$, Rina Amelia ${ }^{2}$ \\ ${ }^{1}$ Department of Biochemistry, Medical Faculty, Universitas Sumatera Utara, Medan, Indonesia; ${ }^{2}$ Department of Public Health, \\ Medical Faculty, Universitas Sumatera Utara, Medan, Indonesia
}

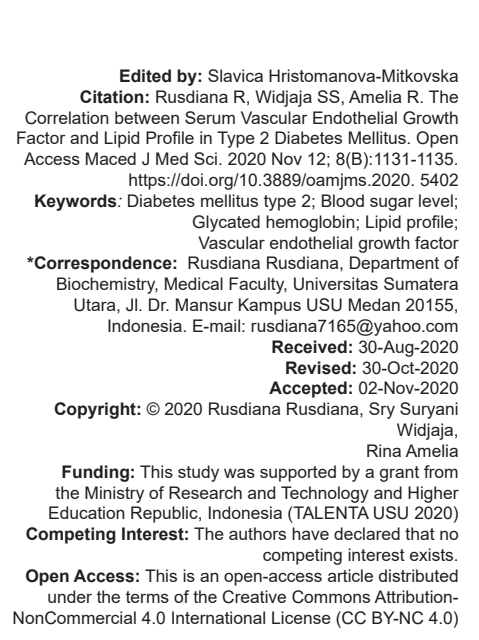

Introduction

Type 2 diabetes mellitus was a metabolic disorder characterized by hyperglycemia and associated with deficiency insulin activity or secretion with absolute and relative [1]. Because of chronic hyperglycemic and insulin resistance caused increasing permeability of blood vessel and disorder endothelial cell (EC). Type 2 diabetes patients have early development of abnormal endothelial function, it caused vasoconstriction, inflammation cell accumulated, migration of smooth muscle cell, and increased cytokine production, which results in plaque development [2]. One of the cytokines secretions is the vascular endothelial growth factor (VEGF) which is a growth factor that induces angiogenesis in vascular ECs [3] and is a significant regulator of angiogenesis in both physiological and pathological conditions. VEGF is a growth factor that can induce angiogenesis in vascular ECs and is a significant regulator of angiogenesis in both physiological and pathological conditions [4].

In the angiogenesis process, the most potent mitogens acting on ECs are the VEGF and basic fibroblast growth factor. The expression of VEGF, which occurs under the influence of hypoxia-inducible factor-1 (HIF-1), starts and maintains a neovascularization process [5].

Processes occurring in diabetes such as hyperglycemia, insulin resistance, hypertension, dyslipidemia, central obesity, and impaired NO synthesis affect blood flow in the vessels and cause tissue hypoxia. Hypoxia is a signal for the induction of angiogenesis and the expression of many genes, including VEGF and VEGFR2, which, due to their functions, may have an impact on the development of diabetic complications [6]. Research has shown that increased angiogenesis is closely associated with the HIF- $1 \alpha$ pathway and the HIF- $1 \alpha /$ VEGF axis plays a pivotal role in tumor angiogenesis [7]. Several types of research that demonstrated that serum VEGF levels were increased in type 2 diabetes mellitus patients with complications [8]. Therefore, VEGF is associated with the development of type 2 diabetes mellitus and is influenced by various factors. In our study we wanted to investigate the correlation between serums VEGF with lipid profile at type 2 diabetes mellitus patients in primary health care in Medan city of North Sumatera, Indonesia. 


\section{Materials and Methods}

In this study, we used 89 of the samples with type 2 diabetes mellitus, we recruited them from the Primary Health Care in Medan city and Primary Health Care in Binjai and Stabat city, North Sumatera, Indonesia. This was conducted from May to July 2020. Patients with known diabetics taking oral hypoglycemic agents or managed with diet or using insulin for glycemic control were included in the study. Permission from the institutional review committee was obtained. Patients were informed with the detail of the study and written consent was obtained from the patients before they participated in the study. Because of the pandemic COVID 19 in our country, we used personal protective equipment for prevention of transmission of the viral COVID 19 and all the samples used the mask when attending to the clinic.

We measured height and weight with the subjects standing in light clothes. Body mass index (BMI) was calculated as the weight in kilograms divided by the square of the height in meters $\left(\mathrm{kg} / \mathrm{m}^{2}\right)$. Blood pressure values were taken as the mean of two measurements after the subjects had been seated for at least $5 \mathrm{~min}$. Subjects fasted overnight to provide a blood specimen. Blood samples were collected (using syringe) and transferred to Paramitha Clinical Laboratory immediately to be conducted fasting blood sugar, glycosylated hemoglobin, and lipid profile. In the Paramitha Clinical Laboratory the examination of fasting blood sugar using hexokinase methods, the examination of glycosylated hemoglobin using HPLC methods, examination of lipid profile using direct CHOD PAP, and GPO PAP methods. We examined the glycosylated hemoglobin test for patients because of this examination as a gold standard for diabetes mellitus patients. VEGF levels were measured with an ELISA assay in laboratories in Medical Faculty, Universitas Sumatera Utara.

The examination VEGF levels in the serum which allows samples to clot for 10-20 min at room temperature. Sample concentrations should be predicted before being used in the assay and samples to be used within 5 days should be stored at $2-8^{\circ} \mathrm{C}$. Samples should be aliquoted or must be stored at $-20^{\circ} \mathrm{C}$ within 1 month or $-80^{\circ} \mathrm{C}$ within 6 months. The samples was centrifuged 2000-3000 RPM for 20 min. All reagents should be brought to room temperature before use. Reconstitute the $120 \mu$ of the standard $(6400 \mathrm{ng} / \mathrm{L})$ with $120 \mu \mathrm{l}$ of standard diluent to generate a $3200 \mathrm{ng} / \mathrm{L}$ standard stock solution. Allow the standard to sit for 15 min with gentle agitation before making dilutions. Prepare duplicate standard points by serially diluting the standard stock solution (3200 ng/L) 1:2 with standard diluent to produce $1600 \mathrm{ng} / \mathrm{L}, 800 \mathrm{ng} / \mathrm{L}$, $400 \mathrm{ng} / \mathrm{L}$, and $200 \mathrm{ng} / \mathrm{L}$ solutions. Standard diluent serves as the zero standards ( $0 \mathrm{ng} / \mathrm{L})$. Any remaining solution should be frozen at $-20^{\circ} \mathrm{C}$ and used within 1 month. Dilution of standard solutions suggested is as follows:

\begin{tabular}{lll}
\hline $3200 \mathrm{ng} / \mathrm{L}$ & Standard No.5 & $120 \mu \mathrm{l}$ Original Standard $+120 \mu \mathrm{l}$ Standard diluent \\
$1600 \mathrm{ng} / \mathrm{L}$ & Standard No.4 & $120 \mu \mathrm{l}$ Standard No.5 $+120 \mu \mathrm{l}$ Standard diluent \\
$800 \mathrm{ng} / \mathrm{L}$ & Standard No.3 & $120 \mu \mathrm{l}$ Standard No. $+120 \mu \mathrm{l}$ Standard diluent \\
$400 \mathrm{ng} / \mathrm{L}$ & Standard No.2 & $120 \mu \mathrm{l}$ Standard No. $+120 \mu \mathrm{l}$ Standard diluent \\
$200 \mathrm{ng} / \mathrm{L}$ & Standard No.1 & $120 \mu \mathrm{l}$ Standard No. $+120 \mu \mathrm{l}$ Standard diluent \\
\hline
\end{tabular}

Dilute $20 \mathrm{ml}$ of wash buffer concentrate $25 x$ into deionized or distilled water to yield $500 \mathrm{ml}$ of $1 \times$ Wash Buffer. If crystals have formed in the concentrate, mix gently until the crystals have completely dissolved.

\section{Assay procedure}

1. Add $40 \mu \mathrm{l}$ sample to sample wells and then add $10 \mu \mathrm{l}$ anti-VEGF antibody to sample wells, then add $50 \mu \mathrm{l}$ streptavidin-HRP to sample wells and standard wells (not blank control well). Mix well. Cover the plate with a sealer. Incubate $60 \mathrm{~min}$ at $37^{\circ} \mathrm{C}$

2. Remove the sealer and wash the plate 5 times with a wash buffer. Soak wells with at least $0.35 \mathrm{ml}$ wash buffer for $30 \mathrm{~s}$ to $1 \mathrm{~min}$ for each wash. For automated washing, aspirate all wells and wash 5 times with wash buffer, overfilling wells with wash buffer. Blot the plate onto paper towels or other absorbent material

3. Add $50 \mu$ l substrate solution A to each well and then add $50 \mu \mathrm{l}$ substrate solution B to each well. Incubate plate covered with a new sealer for $10 \mathrm{~min}$ at $37^{\circ} \mathrm{C}$ in the dark

4. Add $50 \mu \mathrm{l}$ stop solution to each well, the blue color will change into yellow immediately

5. Determine the optical density (OD value) of each well immediately using a microplate reader set to $450 \mathrm{~nm}$ within $10 \mathrm{~min}$ after adding the stop solution.

\section{Calculation of result}

Construct a standard curve by plotting the average OD for each standard on the vertical $(Y)$ axis against the concentration on the horizontal $(X)$ axis and draw a best fit curve through the points on the graph. These calculations can be best performed with computer-based curve-fitting software and the best fit line can be determined by regression analysis.

\section{Typical data}

This standard curve is only for demonstration purposes. A standard curve should be generated with each assay. 


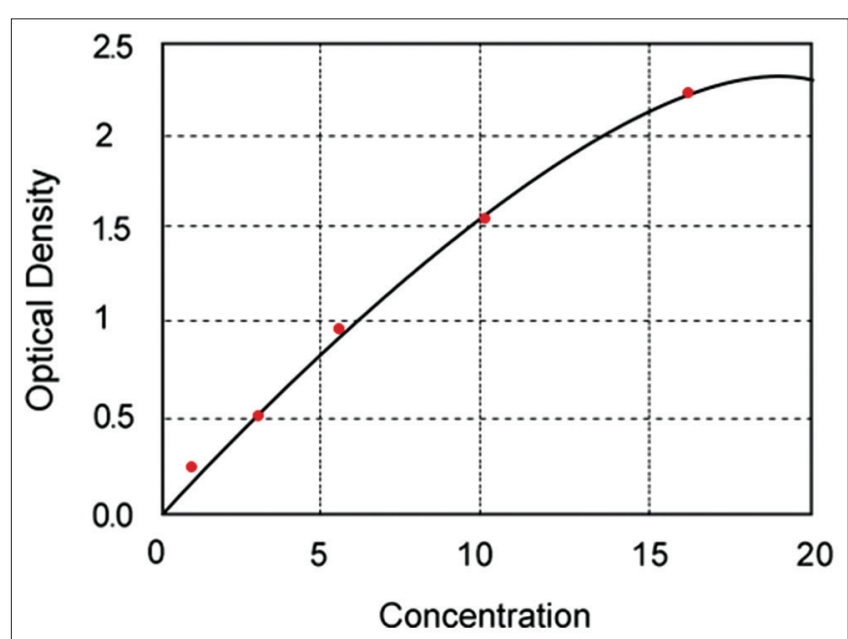

Figure 1: Standard curve

\section{Statistical analysis}

The continuous data were expressed as mean \pm standard deviation (SD). Pearson correlation test was used for checking the normality of distribution. If the data were normally distributed, the correlation test was used. $p<0.05$ was considered as statistically significant.

\section{Results}

We evaluated clinical and laboratory findings in 89 patients with type 2 diabetes mellitus. Of the total number of subjects, $22.5 \%$ (20) were male, and $77.5 \%$ (69) of the subjects were female. The minimum age of the samples 35 years old and the maximum age was 79 years old and the median of age 54 years old. The minimum of the BMI of the samples was 17.63 $\mathrm{kg} / \mathrm{m}^{2}$ and the maximum $46.44 \mathrm{~kg} / \mathrm{m}^{2}$ and the mean $26.29 \mathrm{~kg} / \mathrm{m}^{2}$. The minimum of abdominal circumference was $98 \mathrm{~cm}$ and the maximum $216 \mathrm{~cm}$ and the mean $92.69 \mathrm{~cm}$ and SD $10.47 \mathrm{~cm}$. The minimum of blood pressure of systole and diastole $98 \mathrm{mmHg}$ and 60 $\mathrm{mmHg}$ and maximum $216 \mathrm{mmHg}$ and $113 \mathrm{mmHg}$ with means value $150.96 \mathrm{mmHg}$ and $87.75 \mathrm{mmHg}$ and SD 22.048 and $10.444 \mathrm{mmHg}$. The minimum of blood sugar level (BSL) of the sample $73 \mathrm{mg} / \mathrm{dL}$ and the maximum of BSL levels was $610 \mathrm{mg} / \mathrm{dL}$ and the mean of value $283.55 \mathrm{mg} / \mathrm{dL}$ and SD $137.428 \mathrm{mg} / \mathrm{dL}$. The minimal glycated hemoglobin (HbA1C) value $4.7 \%$ and maximum value $14.7 \%$ with the mean value of $9.1 \%$ and $S D$ value $2.72 \%$. The minimum $\mathrm{HIF}-1 \alpha$ levels were $0.52 \mathrm{ul} / \mathrm{dL}$ and the maximum was $13.45 \mathrm{ul} / \mathrm{dL}$ and the mean was $1.93 \mathrm{ul} / \mathrm{dL}$ and SD $2.46 \mathrm{ul} / \mathrm{dL}$. The minimum VEGF levels of the samples were $111.64 \mathrm{ul} / \mathrm{dL}$ and the maximum was 22052.61 $\mathrm{ug} / \mathrm{dL}$ and the mean was $931.4882 \mathrm{ug} / \mathrm{dL}$ and SD $2405.95 \mathrm{ug} / \mathrm{dL}$ (Tables 1 and 2).
Table 1: Characteristics of the sample

\begin{tabular}{llllll}
\hline Characteristic & Mean & Median & Minimum & Maximum & SD \\
\hline Age (years) & 55.20 & 54 & 35 & 79 & 8.92 \\
BMl (kg/m ${ }^{2}$ ) & 26.2972 & 24.5600 & 17.63 & 46.44 & 5.61078 \\
Abdominal circumference $(\mathrm{cm})$ & 92.69 & 91.00 & 68 & 121 & 10.470 \\
Blood pressure (systole) $\mathrm{mmHg}$ & 150.96 & 150 & 98 & 216 & 22.048 \\
Blood pressure (diastole) $\mathrm{mmHg}$ & 87.75 & 86 & 60 & 113 & 10.444 \\
\hline
\end{tabular}

BMI: Body mass index.

\section{Correlations between VEGF and other}

\section{variables}

In our study, using statistic we assessed the core relationships between serum VEGF levels and other variables in all the type 2 diabetes mellitus patients and found that the serum VEGF level was positively associated with the triglyceride (TG) value $(r=0.255$, $p<0.05)$, cardiac risk index $(r=0.238, p \leq 0.005)$, HIF- $1 \alpha$ $(r=0.659, p<0.005)$, and BMI $(r=0.271, p<0.05)$.

Table 2: Metabolic markers

\begin{tabular}{llllll}
\hline Marker & $\mathrm{n}$ & Minimum & Maximum & Mean & Std. deviation \\
\hline BMI & 89 & 17.63 & 46.44 & 26.2972 & 5.61 \\
LP & 89 & 68 & 121 & 92.69 & 10.47 \\
TDS & 89 & 98 & 216 & 150.96 & 22.05 \\
TDD & 89 & 60 & 113 & 87.75 & 10.44 \\
BSL & 89 & 73 & 610 & 283.55 & 137.43 \\
Hba1c & 89 & 4.70 & 14.70 & 9.1011 & 2.72 \\
Cholesterol & 89 & 136 & 335 & 220.55 & 42.06 \\
LDL & 89 & 51 & 249 & 126.43 & 34.7 \\
HDL & 89 & 24 & 77 & 46.69 & 11.68 \\
TG & 89 & 77 & 708 & 244.37 & 124.04 \\
Durasi & 89 & 1 & 18 & 4.44 & 4.25 \\
VEGF & 89 & 111.64 & 22052.61 & 931.4882 & 2405.95 \\
\hline VEGF: Vascular endothelial growth factor, BSL: Blood sugar level, HbA1c: Glycated hemoglobin,
\end{tabular}
HDL: High-density lipoprotein, LDL: Low-density lipoprotein, TG: Triglycerides, BMI: Body mass index

However, we found no significant correlation ships between VEGF and any of the following factors: Sex, age, HbA1c, BSL, high-density lipoproteincholesterol (HDL-C), and low-density lipoproteincholesterol (LDL-C). We can see in the bellow Table 3.

Table 3: Correlation between VEGF and other variables

\begin{tabular}{lll}
\hline Variable & $\mathrm{P}$ & $\mathrm{R}$ \\
\hline Age & 0.36 & 0.098 \\
Gender & 0.417 & 0.087 \\
BMI & 0.041 & $0.217^{*}$ \\
Abdominal circumference (cm) & 0.166 & 0.148 \\
Blood pressure (systole) mmHg & 0.702 & 0.041 \\
Blood pressure (diastole) mmHg & 0.384 & 0.093 \\
BSL & 0.983 & 0.002 \\
Hba1c & 0.849 & -0.020 \\
Cholesterol & 0.897 & -0.14 \\
LDL-C & 0.591 & -0.058 \\
HDL-C & 0.048 & -0.211 \\
TG & 0.016 & $0.255^{*}$ \\
Cardiac risk index & 0.024 & $0.238^{*}$ \\
Durasi & 0.464 & -0.079 \\
HIF-1 & 0.00 & $0.659^{* *}$ \\
\hline VEGF: Vascular endothelial growth factor, BSL: Blood sugar level, HbA1c: Glycated hemoglobin, \\
HDL: High-density lipoprotein-cholesterol, LDL: Low-density lipoprotein-cholesterol, TG: Triglycerides, \\
BMI: Body mass index. & &
\end{tabular}

\section{Discussion}

There were more females $(77.5 \%)$ than males $(22.5 \%)$ with type $2 \mathrm{DM}$ in this study. The high proportion of females in this study may be due to the nature of the population admitting to primary health care in that more of them seek medical attention than men under the 
favor of having more free time because most of them were housewives. This aim of the study to evaluate the correlation between VEGF with lipid profile (cholesterol, LDL, HDL and Triglyceride) and other marer metabolic at type 2 diabetes mellitus patients.

An important risk factor for type 2 diabetes is obesity and strongly related disorders of lipid parameters. It is estimated that dyslipidemia occurs in $60-80 \%$ of diabetic patients [9]. Angiogenesis is a key factor in adipogenesis [10]. The previous study reports the positive correlation between serum TG levels and VEGF, which is consistent with the study by Peczyńska et al. (2004), which reported patients with incipient diabetic angiopathy [11]. Mahdy et al. (2010) also noted a positive correlation between lipid parameters (total cholesterol and LDL-C) in patients with type 2 diabetes [12]. Besides, Wada et al. (2011) also noted a positive correlation between serum TG and VEGF-A levels [13].

In my study, we found that there was a significant and positive correlation between VEGF with TG, the high TG concentration, so the high VEGF concentration too in my study, we found that there was no significant correlation between VEGF and cholesterol total, LDL, and HDL. Like research by Martynova et al. reported that high TGs were associated with high serum VEGF [14]. However, different research by Sun et al. that there were no significant relationships between VEGF and any of the following factors such as sex, age, BMI, HbA1c, FBG, TG, TC, HDL-C, and LDL-C at type 2 DM [15]. In this study, we found that there was a significant and positive correlation between VEGF and BMl over a large range of BMl $17.63 \mathrm{~kg} / \mathrm{m}^{2}$ and $46.44 \mathrm{~kg} / \mathrm{m}^{2}$. Previous studies indicate that overweight and obese individuals display elevated serum VEGF levels and a statistical BMI dependence of VEGF levels in normal-weight subjects within a wide variance of male and female participants at different metabolic states [16]. The other research reported a positive correlation between plasma VEGF concentrations and BMI over a large range of BMI between $17.6 \mathrm{~kg} / \mathrm{m}^{2}$ and $43.6 \mathrm{~kg} / \mathrm{m}^{2}$ [17]. The same with our study the samples with the lowest BMI $17.63 \mathrm{~kg} / \mathrm{m}^{2}$ which was the low weight and $46.44 \mathrm{~kg} / \mathrm{m}^{2}$ was the obese category. And there was positive correlation BMI with VEGF. Although the research has stated that there was a positive correlation between VEGF and BMI, how the role of VEGF in the pathogenesis of obesity was unclear, Type 2 diabetes mellitus whose pathogenesis is tightly linked to increased BMI [18], it has been shown that the insulin sensitivity is decreased [19] suggesting a direct negative relationship between VEGF concentrations and insulin sensitivity.

Research by Zehetner showed at the retinopathy diabetic patients that $\mathrm{HbA} 1 \mathrm{c}$ levels revealed a significant correlation with plasma VEGF concentrations [20] and the other research showed that VEGF levels in plasma were positively correlated with glycemic control indicators (FBG and $\mathrm{HbA1c}$ ) [21] as we know that the fundamental regulator most widely known to be involved in angiogenesis is VEGF. VEGF is also associated with tumor progression and poor outcomes in various human cancers [22]. In cultured ECs, VEGF has been proven to be induced by elevated levels of glucose and advanced glycation end-products [23]. However, in my study, we found that there was no significant correlation VEGF with $\mathrm{Hba1c}$ and BSL, the same with research by Sun $X$ reported that there were no significant relationships between VEGF with glycemic control (HbA1c, FBG). There are other reasons because VEGF is affected by several factors, including gender, smoking, hyperand hypoglycemia, elevated blood lipids, hypoxia, and activated stress axes, but the major stimulant is cellular hypoxia [24].

The expression of VEGF, which occurs under the influence of HIF1, starts and maintains a neovascularization process [5]. It has become evident that hypoxia plays an important role in all diabetic vascular complications [25]. This research found that that there was a significant and positive correlation between VEGF and HIF-1 $\alpha$ that mean the high HIF-1 $\alpha$ concentration and expressed the high VEGF concentration. Research by Jiang et al. showed that the serum levels of VEGF, HIF- $1 \alpha$, and IGF-I were significantly higher in diabetic patients than in the controls and there were positive correlations existed between VEGF and HIF-1 $\alpha$ [26].

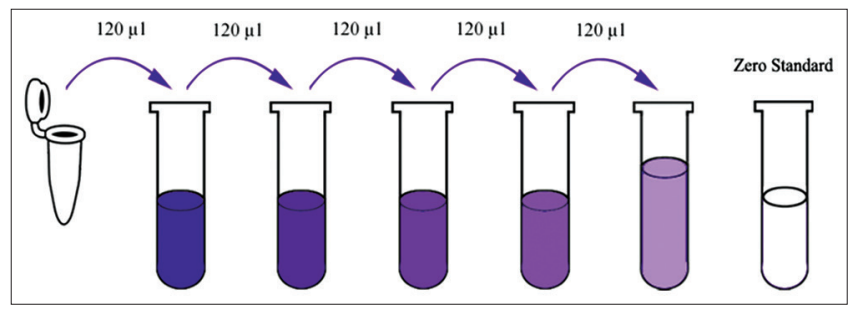

Figure 2: Dilution of the samples

\section{Conclusion}

In our study showed that there was a significant and positive correlation between VEGF and lipid profile (TG), BMI, and HIF-1 $\alpha$.

\section{References}

1. Abou-Seif MA, Youssef AA. Evaluation of some biochemical changes in diabetic patients. Clin Chim Acta. 2004;346(2):16170. https://doi.org/10.1016/j.cccn.2004.03.030

PMid:15256317 
2. Alberti KG, Zimmet P. Epidemiology: Global burden of diseasewhere does diabetes mellitus fit in? Nat Rev Endocrinol. 2013;9(5):258-60. https://doi.org/10.1038/nrendo.2013.54 PMid:23478328

3. Hadi HA, Suwaidi JA. Endothelial dysfunction in diabetes mellitus. Vasc Health Risk Manag. 2007;3(6):853-76.

PMid:18200806.

4. Ferrara N, Gerber HP, Le Couter J. The biology of VEGF and its receptors. Nat Med. 2003;9(6):669-76. https://doi.org/10.1038/ nm0603-669

PMid: 12778165

5. Zielonka TM. Angiogenesis. Part II. Factors that modulate the process of formation of new blood vessels. Allergy Asthma Immunol. 2004;9(1):25-31.

6. Jansson PA. Endothelial dysfunction in insulin resistance and Type 2 diabetes. J Intern Med. 2007;262(2):173-83. https://doi. org/10.1111/j.1365-2796.2007.01830.x

PMid: 17645585

7. Garcia-Maceira P, Mateo J. Silibinin inhibits hypoxia-inducible factor-1alpha and mTOR/p70S6K/4E-BP1 signaling pathway in human cervical and hepatoma cancer cells: Implications for anticancer therapy. Oncogene. 2009;28(3):313-24. https://doi. org/10.1038/onc.2008.398

PMid: 18978810

8. Witmer AN, Vrensen GF, Van Noorden CJ, Schlingemann RO. Vascular endothelial growth factors and angiogenesis in eye disease. Progr Retinal Eye Res. 2003;22(1):1-29. https://doi. org/10.1016/s1350-9462(02)00043-5

PMid:12597922

9. Pacholczyk M, Ferenc T, Kowalski J. The metabolic syndrome. Part II: Its mechanisms of development and its complications. Postepy Hig Med Dosw. 2008;62:543-558.

PMid:18936730

10. Kieć-Wilk B, Dudek W, Dembińska-Kieć A. Nutrigenomics, angiogenesis and obesity. Acta Angiol. 2006;12(4):141-8.

11. Peczyńska J, Urban M, Urban B, Głowińska B, Florys B. Assessment of growth factor levels in adolescents with Type 1 diabetes mellitus and the beginning of diabetic microangiopathy. Endokrynol Diabetol Chor Przemiany Materii Wieku Rozw. 2004;10(1):41-8.

PMid:15355738

12. Mahdy RA, Nada WM, Hadhoud KM, El-Tarhony SA. The role of vascular endothelial growth factor in the progression of diabetic vascular complications. Eye. 2010;24(10):1576-84. https://doi. org/10.1038/eye.2010.86

PMid:20508651

13. Wada H, Ura S, Kitajka S, Satoh-Asahara N, Horie T, Ono K, et al. Distinct characteristics of circulating vascular endothelial growth factor-A and $C$ levels in human subjects. PLoS One. 2011;6(12):e29351. https://doi.org/10.1371/journal. pone.0029351

PMid:22206010

14. Martynova EV, Valiullina AH, Gusev OA, Davidyuk YN, Garanina EE, Shakirova VG, et al. High triglycerides are associated with low thrombocyte counts and high VEGF in the nephropathic epidemic. J Immunol Res. 2016;2016:8528270. https://doi.org/10.1155/2016/8528270 PMid:28053993

15. Sun $X$, Zhang H, Liu J, Wang G. Serum vascular endothelial growth factor level is elevated in patients with impaired glucose tolerance and Type 2 diabetes mellitus. J Int Med Res. 2019;47(11):5584-92. https://doi. org/10.1177/0300060519872033

\section{PMid:31547733}

16. Miyazawa-Hoshimoto S, Takahashi K, Bujo H, Hashimoto N, Saito Y Elevated serum vascular endothelial growth factor is associated with visceral fat accumulation in human obese subjects. Diabetologia. 2003;46(11):1483-8. https://doi.org/10.1007/s00125-003-1221-6 PMid: 14534780

17. Loebig M, Klement J, Schmoller A, Betz S, Heuck N Schweiger $\mathrm{U}$, et al. Evidence for a relationship between VEGF and BMI independent of insulin sensitivity by glucose clamp procedure in a homogenous group healthy young men. PLoS One. 2010;5(9):e12610. https://doi.org/10.1371/journal pone.0012610

PMid:20830305

18. Nammi S, Koka S, Chinnala KM, Boini KM. Obesity: An overview on its current perspectives and treatment options. Nutr J. 2004;3:3. https://doi.org/10.1186/1475-2891-3-3 PMid: 15084221

19. Anderwald C, Pfeiler G, Nowotny P, Anderwald-Stadler M, Krebs M, Bischof MG, et al. Glucose turnover and intima media thickness of internal carotid artery in Type 2 diabetes offspring. Eur J Clin Invest. 2008;38(4):227-37. https://doi. org/10.1111/j.1365-2362.2008.01932.x

PMid:18339003

20. Zehetner C, Kirchmair R, Kralinger M, Kieselbach G. Correlation of vascular endothelial growth factor plasma levels and glycemic control in patients with diabetic retinopathy. Acta Ophthalmol. 2013;91(6):e470-3. https://doi.org/10.1111/aos.12081

PMid:23452413

21. Zhang Q, Fang W, Ma L, Wang ZD, Yang YM, Lu YQ. VEGF levels in plasma in relation to metabolic control, inflammation, and microvascular complications in Type-2: A cohort study diabetes. Medicine. 2018;97(15):e0415 https://doi.org/10.1016/j. juro.2018.02.2987 PMid:29642210

22. Brychtova S, Bezdekova M, Brychta T, Tichy M. The role of vascular endothelial growth factors and their receptors in malignant melanomas. Neoplasma. 2008;55(4):273-9.

PMid: 18505336

23. Schlingemann RO, Van Noorden CJ, Diekman MJ, Tiller A Meijers JC, Koolwijk P, et al. VEGF levels in plasma in relation to platelet activation, glycemic control, and microvascular complications in Type 1 diabetes. Diabetes Care. 2013;36(6):1629-34. https://doi.org/10.2337/dc12-1951

PMid:23321217

24. Sandhofer A, Tatarczyk T, Kirchmair R, Iglseder B, Paulweber B, Patsch JR, et al. Are plasma VEGF and its soluble receptor sFlt-1 atherogenic risk factors? Cross-sectional data from the SAPHIR study. Atherosclerosis. 2009;206(1):265-9. https://doi. org/10.1016/j.atherosclerosis.2009.01.031 PMid:19237157

25. Cameron NE, Eaton SE, Cotter MA, Tesfaye S. Vascular factors and metabolic interactions in the pathogenesis of diabetic neuropathy. Diabetologia. 2001;44(11):1973-88. https://doi. org/10.1007/s001250100001

\section{PMid:11719828}

26. Jiang $F$, Tang $Y T$, Guo L, Jiao $X Y$. The role of insulin-like growth factor I and hypoxia-inducible factor $1 \alpha$ in vascular endothelial growth factor expression in Type 2 diabetes. Ann Clin Lab Sci. 2013;43(1):37-44.

PMid:23462604 